\title{
Rice Seedling and Plant Development as Affected by Increasing Rates of Penoxsulam under Controlled Environments ${ }^{1}$
}

\author{
Desenvolvimento de Plântulas e Plantas Adultas de Arroz em Função de Doses Crescentes de \\ Penoxsulam em Ambiente Controlado
}

\author{
CONCENÇO, G. ${ }^{2}$, LOPES, N.F. ${ }^{3}$, MORAES, D.M. ${ }^{3}$, ANDRES, A. ${ }^{4}$ e MELO, P.T.B.S. ${ }^{5}$
}

\begin{abstract}
Rice is a major staple in many countries. Weed control is one of the factors limiting higher rice yield. ALS (acetolactate synthase)-inhibiting herbicides are desirable weed control herbicides because of their high efficacy, low toxicity to mammalians, and low rates used. An important herbicide characteristic is high selectivity to the crop, since it facilitates fast crop establishment and greater crop advantage over the weeds. The objectives of this work were to study the effects of increasing rates of the ALS-inhibiting herbicide penoxsulam on seed integrity and germination, and seedling and plant development of rice cv. BRS Pelota under controlled laboratory and greenhouse conditions. The results showed that penoxsulam affected rice germination and seedling and plant growth at rates above $54 \mathrm{~g}$ a.i. $\mathrm{ha}^{-1}$, and that penoxsulam is safe for rice seedling development at the currently recommended rates.
\end{abstract}

Keywords: initial establishment, herbicide, Oryza sativa.

RESUMO - O arroz é componente importante da dieta humana em vários países. Entre os fatores que limitam o aumento na sua produtividade está o controle de plantas daninhas. Os herbicidas inibidores da ALS (acetolactato sintase) são preferidos em razão da alta eficiência no controle de plantas daninhas, da baixa toxicidade aos mamíferos e das baixas doses utilizadas. Uma característica importante que um herbicida deve possuir é a alta seletividade à cultura, pois ela implica estabelecimento mais rápido, com vantagem competitiva sobre as plantas daninhas. O objetivo deste trabalho foi estudar os efeitos do herbicida inibidor da ALS penoxsulam em doses crescentes sobre a integridade e germinação das sementes, bem como sobre o desenvolvimento inicial das plântulas e da planta adulta do cultivar BRS Pelota, sob condições de ambiente controlado (laboratório e casa de vegetação). Os resultados mostraram que o penoxsulam afetou a germinação e o crescimento de plântulas e plantas adultas nas doses acima de $54 \mathrm{~g}$ i.a. ha ${ }^{-1}$ e que ele é seguro para o desenvolvimento da plântula de arroz nas doses atualmente recomendadas.

Palavras-chave: estabelecimento inicial, herbicida, Oryza sativa.

\section{INTRODUCTION}

Rice is extensively used for human consumption in many countries. It is cultivated all over the world, mainly in the Asiatic continent, and is an important source of carbohydrate (Azambuja et al., 2002). World rice trade is segmented according to local preferences in relation to grain type and quality, determined by the importing countries. The consumption per capita around the world is $87 \mathrm{~kg}$ per year, with Asia being the greatest consumer (FAO, 2000).

In Brazil the main production areas are located in the southern region (Rio Grande do

Recebido para publicação em 21.3.2005 e na forma revisada em 24.2.2006.

2 Eng.-Agr., Master student in Plant Physiology, CNPq, Universidade Federal de Pelotas - UFPel, Caixa Postal 354, 90010-900 Capão do Leão-RS, <gconcenco@yahoo.com.br>. ${ }^{3}$ Prof. D.S., DB/UFPel; ${ }^{4}$ Weed Science Researcher, M.S., Embrapa Clima Temperado, BR 392, km 78, Caixa Postal 403, 96001-970 Pelotas-RS. ${ }^{5}$ Eng.-Agr., D.S. in Seed Science, UFPel. 
Sul, Santa Catarina), and Goias located in the Mid - western region where highland rice is grown. Almost all the Brazilian production is consumed in situ because Brazil is not selfsufficient. In the state of Rio Grande do Sul, rice grain yields are comparable to those obtained in other productive regions of the world. However, problems with high costs of production, high red rice infestations, and occurrence of abiotic factors (such as cold at the flowering stage), limit regional production to about 10 ton ha-1 (Magalhães Jr. et al., 2002).

Weed control is indispensable to guarantee economic profit. Herbicides contribute significantly to increase yield, mainly under the conventional sowing system, where herbicidal chemicals are the main method used for weed control (Magalhães Jr. et al., 2002). Without control, weeds can reduce grain yield in as much as 80\% (Smith, 1988). Rice establishment, regardless of the cultivation system, is a critical component of the practices used to ensure competitive advantage of rice over weeds.

Amongst the weeds occurring in rice culture, red rice is characterized for its difficult control, junglerice (Echinochloa colona) and barnyardgrass (Echinochloa crusgalli) by high infestations around the world, and cyperaceous weeds, which are problematic in many fields (Andres \& Machado, 2004). In conventional rice growing systems which are strongly dependent on chemicals, there are many possible options for weed control. A key problem is the control of cyperaceous weeds in pre-emergence, before competition begins. The main difficulty in preemergence is to achieve broad spectrum weed control using just a single product.

Herbicides with a wider spectrum of action and smaller risks to human and animal health have been developed over time. The desire for foods containing lower levels of herbicide residues has promoted the development of a new herbicide group inhibiting the enzyme ALS (acetolactate synthase), that controls weeds efficiently with minimal environmental impacts (Vidal, 2002). ALS is the first common enzyme responsible for the synthesis of branched chain amino acids valine, leucine and isoleucine (Shaner, 1991; Eberlein et al., 1997) and it is also present in chloroplasts. ALS-inhibiting herbicides are widely used because they control many weeds at low rates, provide excellent crop safety, and have low mammalian toxicity (Beyer et al., 1988; Brown, 1990; Newhouse et al., 1991). Organisms other than plants are not strongly affected because they do not possess this enzyme (Leite et al., 1998).

Very efficient herbicides can cause phytotoxicity to the crop resulting in severe yield reductions. ALS-inhibiting herbicides have selectivity to rice culture. Four chemical classes are known: sulfonylureas, imidazolinones, triazolopyrimidine sulfonanilides, and pyrimidinyl benzoates (Sprague et al., 1997).

Weed seedlings emerging with or just before the rice are a major problem because they interfere more with crop growth and development than do later emerging weeds (Schweizer et al., 1998). In some situations, when water is a limiting factor, interaction between water management and application of a residual pre-emergence herbicide is a powerful tool to bring grain yield to a maximum level.

Water management is of great importance in weed control and increasing grain yield in rice (Gomes et al., 1999). Water reduces the $\mathrm{O}_{2}$ availability to roots (De Datta et al., 1979; Gondin, 1983; Grillo, 1985). Thus, a preemergence herbicide should maintain active weed control at least until flooding starts (Freitas, 2004).

A new ALS-inhibiting herbicide, penoxsulam, has recently been made available for use in irrigated rice, combining a wide spectrum of action selectivity to rice culture (Freitas, 2004; Pinto et al., 2004), and preemergence control of cyperaceous weeds. However, it is important to know how rice plants respond to this new herbicide. Efficient weed control must be associated with minimal damage to the crop, in order to afford the best initial establishment. This will allow the crop to have the advantage in development, covering weedy plants, and consequently avoiding greater infestations during the growing season.

The objectives of this work were to study the influence of increasing rates of penoxsulam, applied in pre-emergence, on seed integrity and germination, initial development of the seedlings and adult plant of rice cv. BRS Pelota, 
under controlled conditions in the laboratory and greenhouse.

\section{MATERIAL AND METHODS}

Two experiments were conducted under controlled conditions. The first was carried out at the Seed Development Laboratory, Department of Botany, Universidade Federal de Pelotas, Capão do Leão-RS, from April to June, 2004. The second was installed under greenhouse conditions at Embrapa Clima Temperado, Capão do Leão-RS, from May to June, 2004.

The laboratory experiment was conducted at different phases. An imbibition's curve for rice cv. BRS Pelota was determined initially (Figure 1). A conductivity test was performed to determine the influence of herbicide penoxsulam on membrane integrity. The experimental design was completely randomized with three statistical replications and four test replications for penoxsulam rates of 0, 49, 98, 147 and $196 \mathrm{mg}$ a.i. $\mathrm{L}^{-1}$. Based on preliminary results from the imbibition curve, fifty seeds were soaked in herbicide solutions for a period of one hour. Conductivity was measured $0,1,2,3$ and 24 hours after imbibition, according to Krzyzanowski et al. (1991).

One hundred seeds were sowed in Germitest papers pre-soaked in herbicide solutions for one hour. Twelve replications were used for each rate (four test and three

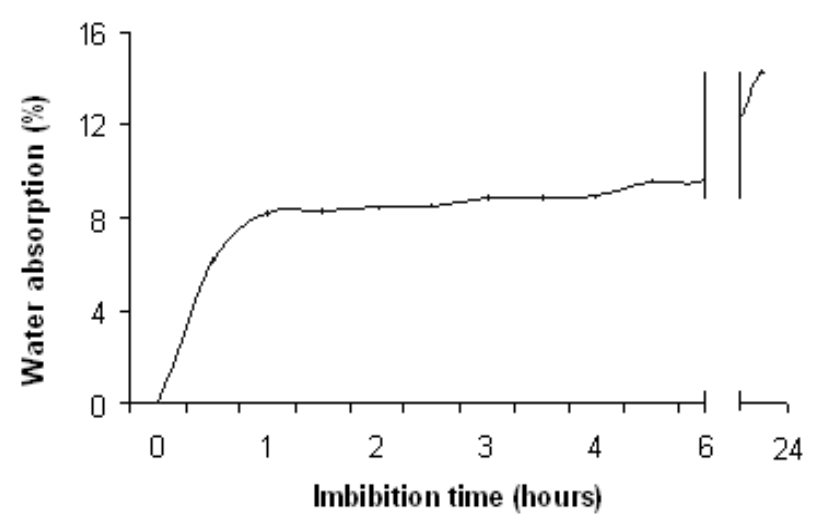

Figure 1 - Water absorption by rice seeds cv. BRS Pelota as a function of imbibition time. UFPel/DB, Capão do LeãoRS, 2005. statistical replications). The replications of each rate were put into a plastic pack and all treatments placed in the germinator regulated to $25^{\circ} \mathrm{C}$. The following tests germination curve, root and shoot fresh and dry matter, length and water content, and germination at 7 and 14 days were determined for the same rates used for the conductivity test.

The second experiment was conducted under greenhouse conditions with treatments consisting of penoxsulam rates of $0,18,36$, 54 and $72 \mathrm{~g}$ a.i. ha ${ }^{-1}$. One hundred seeds were sowed in washed sand (one experimental unit), at $20 \mathrm{~mm}$ depth, with two test and four statistical replications. The herbicide was applied with a precision apparatus using four nozzles TeeJet 110.015 , propelled by $\mathrm{CO}_{2}$ at 35 PSI and a flow rate of $150 \mathrm{~L} \mathrm{ha}^{-1}$ outlet. The herbicide was applied two days after sowing, outside the greenhouse, without wind. The experimental units were irrigated to near field capacity two hours before herbicide applications. The experiment was conducted over a 20 day period (6 days before and 14 days after emergence).Fresh and dry shoot weight, length, $\mathrm{I}_{50}$ (rate causing $50 \%$ of reduction on the measured parameter), correlation analysis between length and fresh weight, water content, germination and emergence curve were determined.

The experimental data were submitted to analysis of variance (ANOVA) at 5\% level with polynomial regression when significant.

\section{RESULTS AND DISCUSSION}

The ideal time for rice seed imbibition was one hour (Figure 1), coinciding with results of Krzyzanowski et al. (1991).

Electrical conductivity increased with increasing penoxsulam rates, especially for the highest rate tested, and ranged from 0.46 to $0.56 \mathrm{~S} \mathrm{~m}^{-1} \mathrm{~g}^{-1}$ seed for $24 \mathrm{~h}$ (Figure 2). Electrical conductivity was primarily affected by imbibition's time rather than by the rate used (Figure 2). The electrical conductivity is thought to be related directly with the ability of the seed to germinate in field conditions. The increasing rate in electrical conductivity must decrease the seed's ability to germinate (Colete et al., 2003a, b). 
Penoxsulam reduced shoot and root length, up to $66 \%$ and $91 \%$, respectively, at a rate of $196 \mathrm{mg}$ a.i. $\mathrm{L}^{-1}$ (Figure 3). In the young leaves of susceptible plants, cell division and elongation are strongly inhibited within a few hours after application (Shaner, 1991; Leite et al., 1998).

Increasing penoxsulam rates reduced the water content in roots but not in the shoots, and a polynomial regression curve could not be fit to the shoot data (Figure 4). Increasing penoxsulam rates reduced shoot and root fresh weight (Figure 6), similar to the reductions in shoot and root length (Figure 3), showing a strong correlation between fresh weight and cell elongation. However, root and shoot length was reduced more drastically than root dry (Figure 5) and fresh (Figure 6) weight. Shoot and root dry weight (Figure 5) was reduced less drastically than fresh weight (Figure 6), confirmed by water content (Figure 4), decreasing as a function of increasing penoxsulam rates. Root water content was reduced with increasing rates of penoxsulam causing greater reductions in fresh matter than in dry matter (Figures 5 and 6).

The water content reduction caused cellular contraction, decreasing turgor pressure, consequently concentrating solutes into the cells. In addition, turgor-dependent functions such as leaf expansion and root elongation, are significantly more sensitive to water deficit (Bressan et al., 2004). This helps to explain why root system expansion was more affected than leaf fresh weight.

The minimal effect of penoxsulam rates on electrical conductivity (Figure 2) reflected a homogeneous capacity to germinate for all treatments (Figures 7 and 8). In addition, penoxsulam caused a slight retardation in rice germination at about 1 day (Figure 8).

The percentage of germinated seeds decreased linearly with increasing penoxsulam rates at 7 and 14 days after sowing (DAS), showing similarity and stability in herbicide effects over time (Figure 7). Penoxsulam began to act soon after application, resulting in immediate damages to plants. Almost all seeds were germinated at 7 DAS with only two or three percent additional germination at 14 DAS (Figure 7). The correlation analysis between these two evaluations indicated similarity at $5 \%$ level, with an absolute correlation of 0.891 . The 2-3\% decrease in germination was not a limiting factor for seeds, mainly because rice is a very plastic crop (Magalhães Jr et al., 2004), and little seed germination reduction could be offset by tillering.

Penoxsulam reduced seedling growth and had little effect on rice germination (Figure 8). Penoxsulam, an ALS-inhibiting herbicide, did not affect seed germination in considerable amounts, but did inhibit roots and shoots because these herbicides inhibit mitosis (Leite et al., 1998). In addition, these herbicides accumulate in meristems, causing clorosis followed by necrosis in damaged plants. These symptoms were not observed under laboratory or greenhouse conditions at any penoxsulam rate tested.

It is important to emphasize that this experiment was conducted under a controlled environment, and that the seed stayed permanently soaked in the herbicide solutions. This may differ from actual field conditions, where ambient effects (leaching, degradation, or adsorption to colloidal particles) can attenuate herbicide presence and consequently absorption by the root system (Worthing et al, 1982).

The interaction between an adsorbent surface and herbicide molecules causes the adsorbate to be attracted to the surface, reducing its concentration in the soil solution.

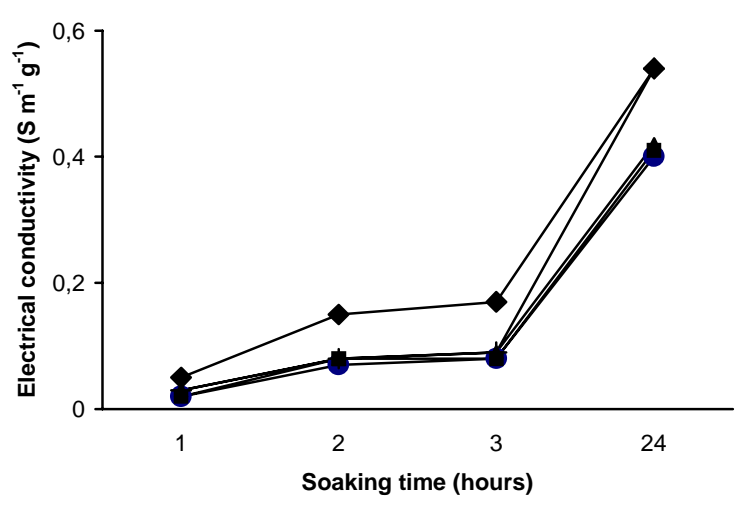

Figure 2 - Electrical conductivity of rice seeds cv. BRS Pelota as a function of soaking time for several solutions of penoxsulam, where zero $(\bullet) ; 49(\boldsymbol{\bullet}) ; 98(\boldsymbol{\Delta}) ; 147(+) ; 196$ (•) mg a.i. L-1 ${ }^{-1}$ UFPel/DB, Capão do Leão-RS, 2005. 


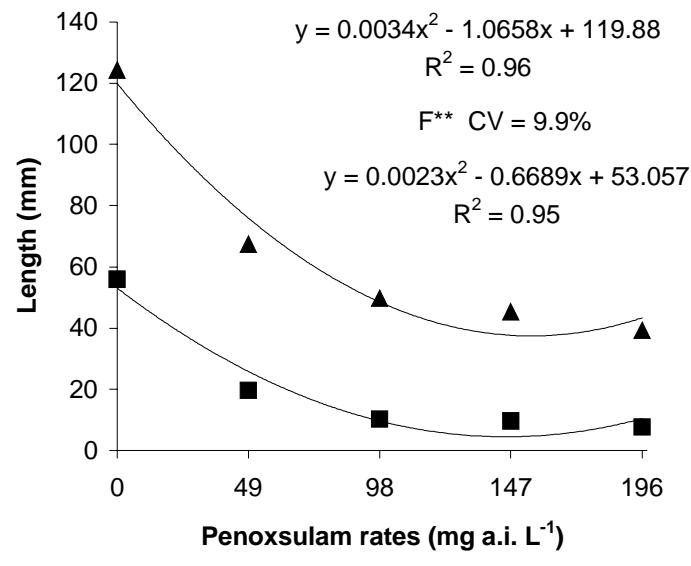

Figure 3 - Shoot ( $\mathbf{\Delta}$ ) and root (অ) length of rice seedlings cv. BRS Pelota as a function of penoxsulam rates. UFPel/DB, Capão do Leão-RS, 2005.

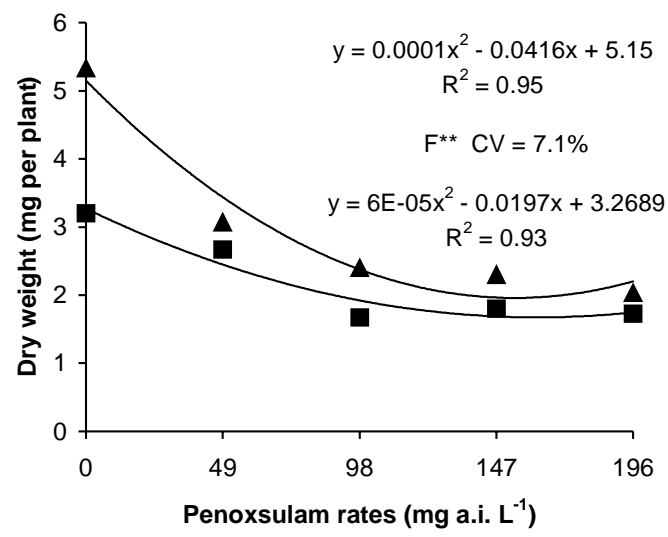

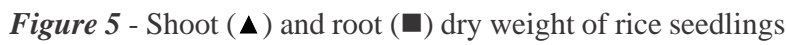
cv. BRS Pelota as a function of penoxsulam rates. UFPel/ DB, Capão do Leão-RS, 2005.

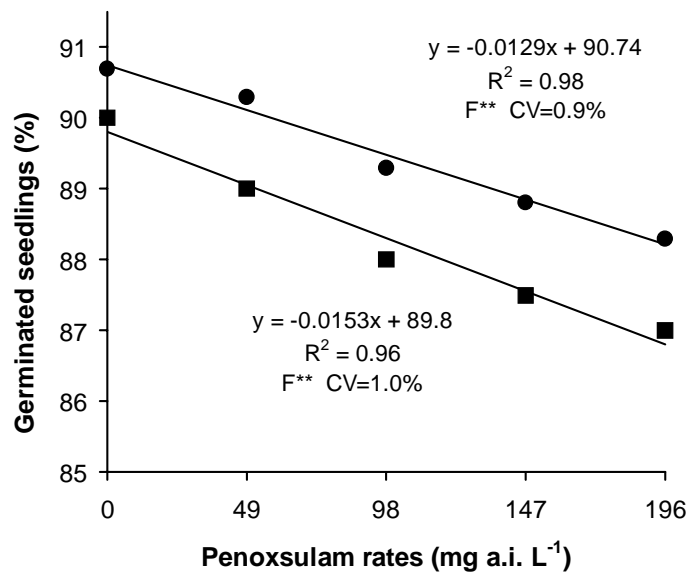

Figure 7 - First count ( $\mathbf{\square}$ ) and germination standard test $(\bullet)$ of rice seeds cv. BRS Pelota as a function of penoxsulam rates under controlled environment. UFPel/DB, Capão do LeãoRS, 2005.

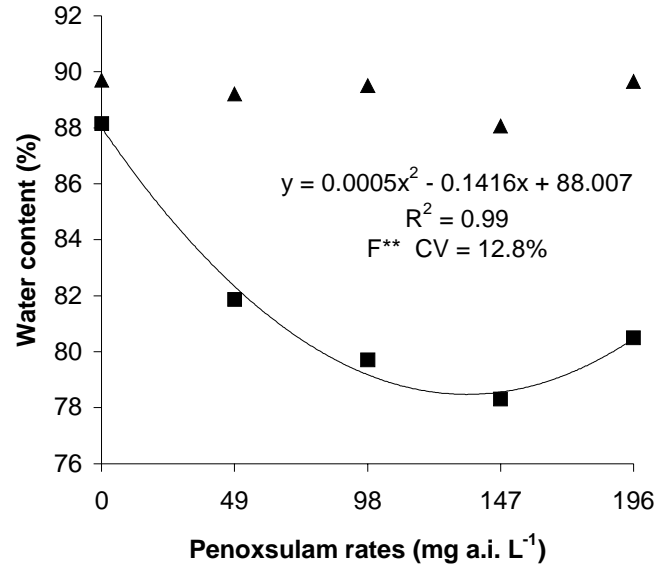

Figure 4 - Shoot (A) and root ( $\square)$ water content of rice seedlings $\mathrm{cv}$. BRS Pelota as a function of penoxsulam rates. UFPel/ DB, Capão do Leão-RS, 2005.

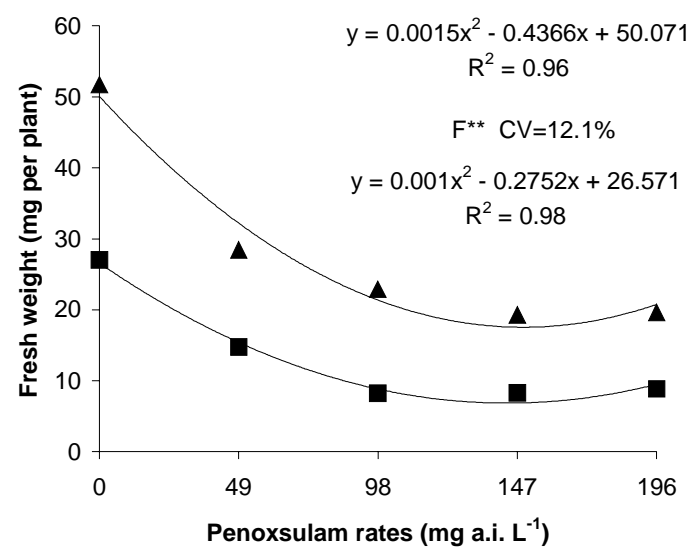

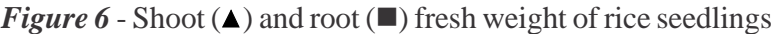
cv. BRS Pelota as a function of penoxsulam rates. UFPel/ DB, Capão do Leão-RS, 2005.

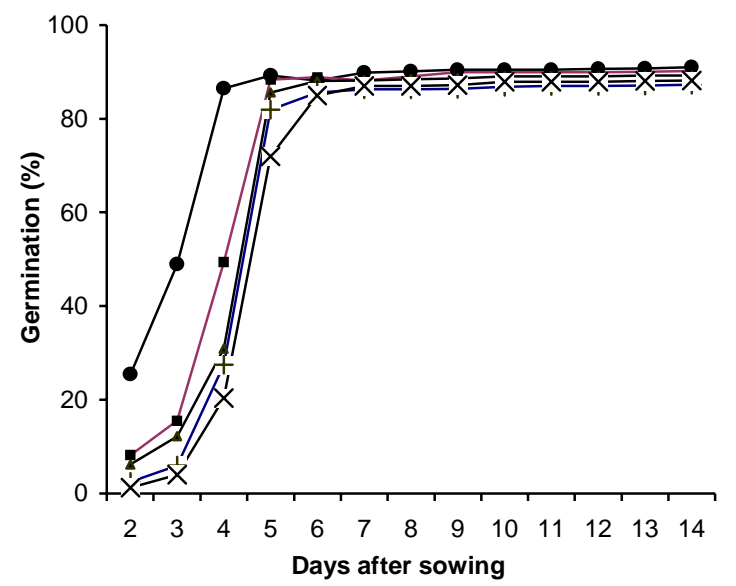

Figure 8 - Germination curve of rice seeds cv. BRS Pelota as a function of days after sowing and penoxsulam rates, where zero $(\bullet), 49(\mathbf{\bullet}), 98(\boldsymbol{\Delta}), 147(+)$ and $196(\mathbf{x}) \mathrm{mg}$ a.i. L ${ }^{-1}$. UFPel/DB, Capão do Leão-RS, 2005.

Planta Daninha, Viçosa-MG, v. 24, n. 1, p. 131-139, 2006 
As a result, the effect of a given rate varies with soil type, and the levels of herbicidal imbibition observed under greenhouse conditions using washed sand would probably be attenuated in field conditions with increasing clay content (Walker et al., 1982).

For the second experiment, conducted under greenhouse conditions, fresh weight, dry weight and plant lenght were reduced (Figure 9,10 and 12) by increasing penoxsulam rates. Correlation between plant length and fresh

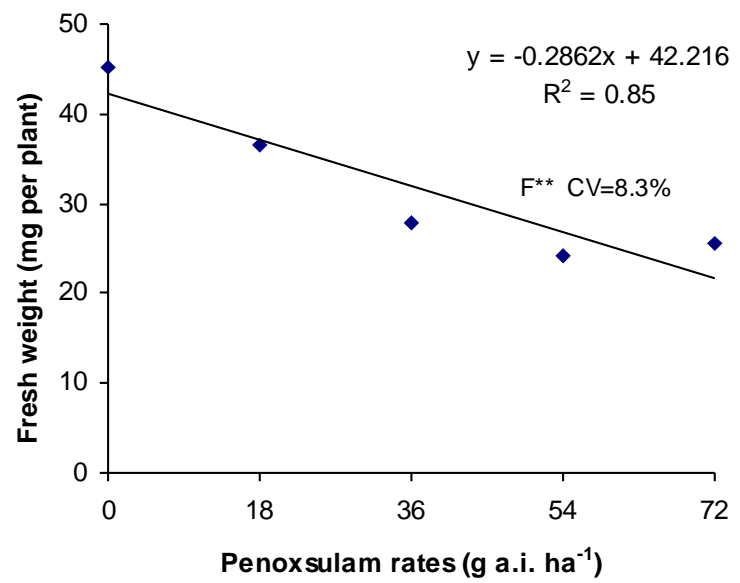

Figure 9 - Shoot fresh weight of rice seedlings cv. BRS Pelota as a function of penoxsulam rates, growing under greenhouse conditions. UFPel/DB, Capão do Leão-RS, 2005.

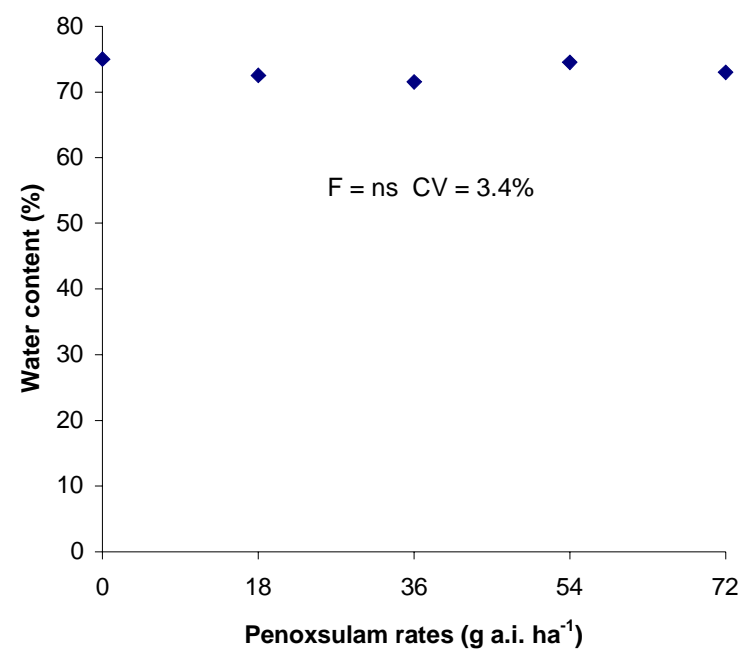

Figure 11 - Shoot water content of rice seedlings cv. BRS Pelota as a function of penoxsulam rates, growing under greenhouse conditions. UFPel/DB, Capão do Leão-RS, 2005. weight reductions showed similarity at 1\% level, with a correlation of 0.98. Consequently, herbicidal reduction in fresh weight should result from direct reduction in length rather than from a direct consequence of herbicidal application, because leaves were not narrowed with increasing penoxsulam rates.

In contrast to laboratory conditions (Figure 4), the water content was not affected by penoxsulam rates (Figure 11), probably because plants in this experiment were not constantly in contact with herbicide solutions

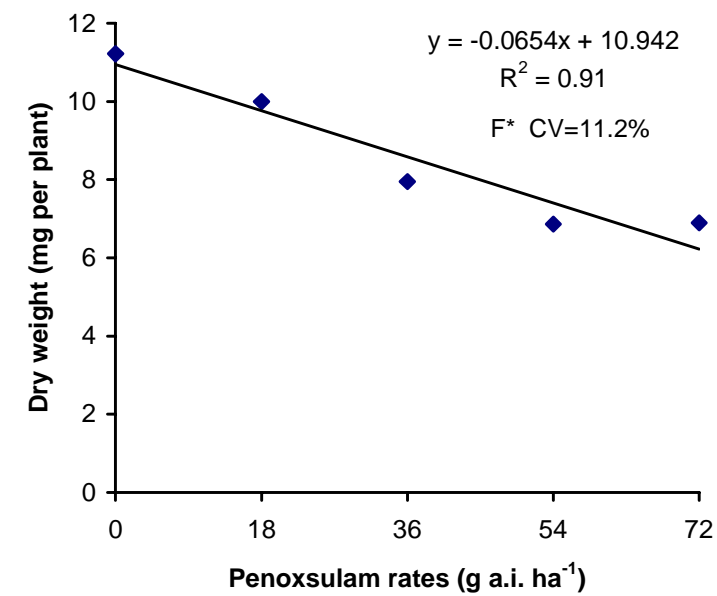

Figure 10 - Shoot dry weight of rice seedlings cv. BRS Pelota as a function of penoxsulam rates, growing under greenhouse conditions. UFPel/DB, Capão do Leão-RS, 2005 .

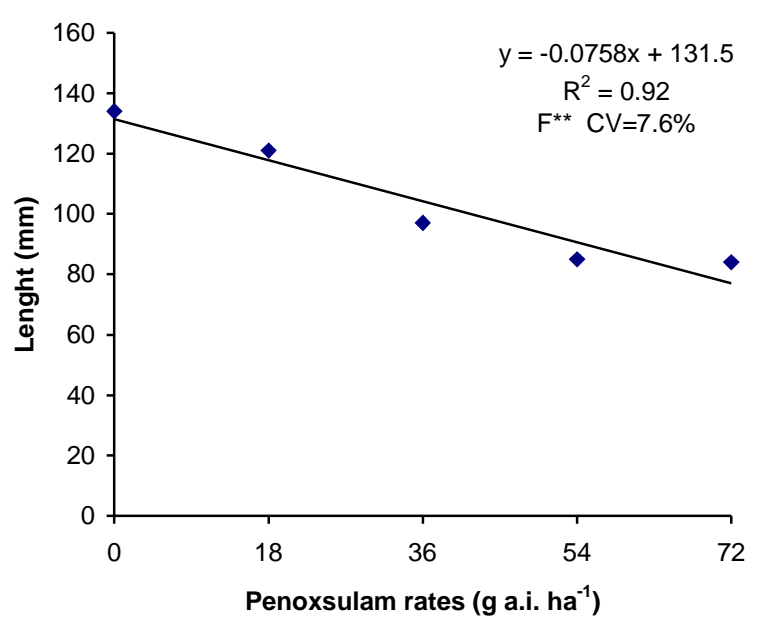

Figure 12 - Shoot length of rice seedlings cv. BRS Pelota as a function of penoxsulam rates, growing under greenhouse conditions. UFPel/DB, Capão do Leão-RS, 2005. 
as they were under laboratory conditions. Following this tendency, the presence of the herbicide and consequently its absorption by the root system, would probably be attenuated under field conditions (Worthing et al, 1982).

Penoxsulam reduced plant length linearly with increasing rates. At the greatest rate (72 $\mathrm{g}$ a.i. ha $^{-1}$ ) the reduction reached about $30 \%$ of that observed for the control treatment (Figure 12). This reduction was enhanced under laboratory conditions (Figure 3). External phytotoxicity symptoms, such as necrosis, yellowing or blighting, were not observed in this experiment.

It is important to note that the sowing was done in washed sand rather than soil, where part of the herbicide should remain adsorbed to the colloidal particles. Under these conditions, the herbicide is totally available because the experimental units were not drilled and volatilization losses are minimized (Leite et al., 1998). Thus, under these conditions, other factors like microbial degradation are drastically reduced (Mattos, 2004).

The $\mathrm{I}_{50}$ (rate that reduces the evaluated parameter by $50 \%$ ) rates for plant length and fresh weight were of $85.09 \mathrm{~g}$ a.i. ha ${ }^{-1}$ and $68.54 \mathrm{~g}$ a.i. ha ${ }^{-1}$, respectively, while rates of 36 - $42 \mathrm{~g}$ a.i. $\mathrm{ha}^{-1}$ are effective in weed control with high selectivity to the crop (Andres et al., 2004a, b; Menezes et al., 2004; Pinto et al., 2004). These rates are almost twice lower than the $\mathrm{I}_{50}$ values.

The emergence curve (Figure 13) was not affected by the penoxsulam rates, and both initial emergence speed and total emerged plant number were not significantly influenced. Penoxsulam did not directly affect rice seedlings, contributing to rapid stand establishment which is essential for optimum crop development during the growing season (Concenço et al., 2004).

Summarizing, membrane integrity was affected by time of imbibition, with discrete effects of increasing rate; in permanent contact with the solution, root and shoot length, water content, fresh and dry weight were affected at rates between 147 and $196 \mathrm{mg}$ a.i. $\mathrm{L}^{-1}$. Seed vigor was not reduced, and seed germination was not affected at considerable amounts. In addition, rice establishment was not affected by penoxsulam at rates below $72 \mathrm{~g}$ a.i. ha ${ }^{-1}$. Thus penoxsulam was safe at currently tested rates, showing discrete effects over rice cv. BRS Pelota. Finally, penoxsulam did not cause visible phytotoxicity to rice plants.

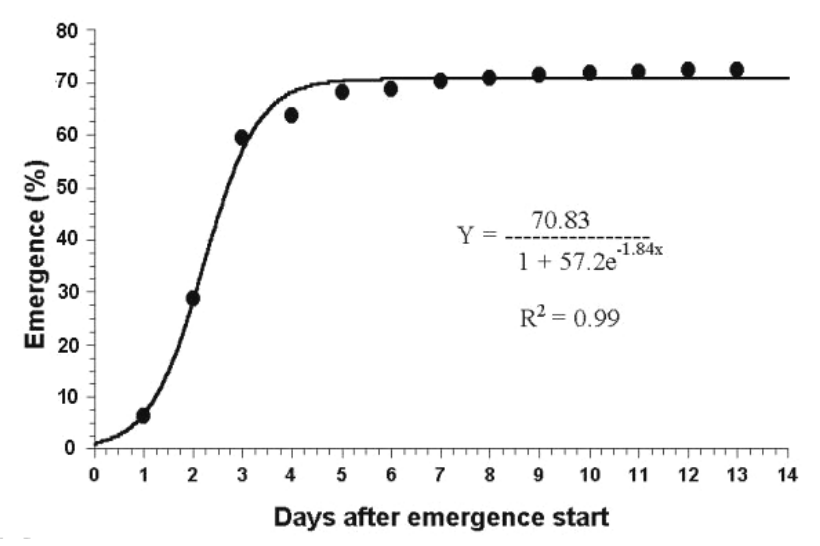

Figure 13 - Emergence curve of rice seedlings cv. BRS Pelota as average of penoxsulam rates in function of days after emergence start under greenhouse conditions. UFPel/DB, Capão do Leão-RS, 2005.

When working with penoxsulam under field conditions, phytotoxicity symptoms should be evaluated mainly as shoot and root growth reductions. Common herbicide phytotoxicity symptoms, like necrosis, yellowing and blighting, if observed, could be due to external factors. Besides, the water content is a parameter to observe when studying penoxsulam phytotoxicity before it could be visible in other variables.

\section{LITERATURE CITED}

ANDRES, A.; MACHADO, S. L. O. Plantas daninhas em arroz irrigado. In: GOMES, A. S.; MAGALHÃES JR., A. M. (Eds.). Arroz irrigado no Sul do Brasil. Brasília: Embrapa Informação Tecnológica, 2004. p. 457-546.

ANDRES, A. et al. Alternativas de controle químico de plantas daninhas em arroz irrigado, submetido a diferentes períodos de irrigação. In: CONGRESSO BRASILEIRO DA CIÊNCIA DAS PLANTAS DANINHAS, 24., 2004, São Pedro. Anais... Londrina: SBCPD, 2004a. CD-ROM.

ANDRES, A. et al. Utilização de pré e pós emergentes no controle de Echinochloa sp. e Aeschynomene sp. no sistema convencional de semeadura do arroz. In: CONGRESSO BRASILEIRO DA CIÊNCIA DAS PLANTAS DANINHAS, 24., 2004, São Pedro. Anais... Londrina: SBCPD, 2004 b. CD-ROM. 
AZAMBUJA, I. H. V.; MAGALHÃES Jr., A. M.;

VERNETTI Jr., F. J. Situação da cultura do arroz no mundo e no Brasil. In: AZAMBUJA, I. V. et al. (Eds.). Série Culturas - Arroz. Porto Alegre: Comissão de Agricultura, Pecuária e Cooperativismo da Assembléia Legislativa do Estado do Rio Grande do Sul, 2002. p. 11-22.

BEYER, E. M. et al. Sulfonylureas. In: KEARNEY, P. C.; KAUFMAN, D. D. (Eds.). Herbicides: chemistry, degradation, and mode of action. New York: Marcel-Dekker, 1988. p. $117-190$

BRESSAN, R. A.; HASEWAGA, P. M.; LOCY, R. D. Fisiologia do estresse. In: TAIZ, L.; ZEIGER, E. (Eds.). Fisiologia vegetal. Porto Alegre: Artmed, 2004. p. 613-643.

BROWN, H. M. Mode of action, crop selectivity, and soil relations of the sulfonylurea herbicides. Pest. Sci., v. 29, p. 263-281, 1990.

COLETE, J. C. F.; VIEIRA, R. D.; DUTRA, A. S. Relação entre os resultados do teste de condutividade elétrica e da emergência de plântulas de soja. Inf. ABRATES, v. 13, n. 3B, p. 12, 2003a.

COLETE, J. C. F.; VIEIRA, R. D.; DUTRA, A. S. Condutividade elétrica e emergência de plântulas de soja. Inf. ABRATES, v. 13, n. 3B, p. 13, 2003 b.

CONCENÇO, G. et al. Efeito do herbicida penoxsulam sobre o desenvolvimento inicial da cultivar de arroz BRS-Pelota. In: CONGRESSO DE INICIAÇÃO CIENTÍFICA, 13., 2004, Pelotas. Anais... Pelotas: UFPel, 2004. CD-ROM.

DE DATTA, S. K.; LEVINE, G.; WILLIAMS, A. Manejo del agua y necesidades del riego del arroz. In: DE DATTA, S. K (Ed.). Cultivo del Arroz: manual de produción Limusa. Mexico: Escuela de Agricultura, Universidad de Filipinas, Instituto Internacional para Investigación del Arroz, 1979. p. 121-135.

EBERLEIN, C. V. et al. Altered acetolactate synthase activity in ALS-inhibitor resistant prickly lettuce (Lactuca serriola). Weed Sci., v. 45, p. 212-217, 1997.

FAO-FAOSTAT. Database results. Disponível em: <http:// www.apps1.fao.org/servelet>. Acesso em: 8 jun. 2000.

FREITAS, G. D. Desempenho do arroz (Oryza sativa L.) cv. BRS-Pelota e controle de capim-arroz (Echinochloa sp.) submetidos a quatro épocas de entrada de água após aplicação de doses reduzidas de herbicidas. 2004. $54 \mathrm{f}$. Dissertação (Mestrado em Produção Vegetal) - Universidade Federal de Pelotas, Pelotas, 2004.

GOMES, A. S. et al. Manejo da água em arroz irrigado: implicações e recomendações técnicas. In: GOMES, A. S.; PAULETTO, E. A. (Eds.). Manejo do solo e da água em áreas de várzea. Pelotas: Embrapa Clima Temperado, 1999. p. 103-200.
GONDIN, L. A. P. Irrigação e drenagem. Lav. Arroz., v. 37, p. 347,1983 .

GRILLO, F. M. Diseño de sistemas del riego e distribuición de agua. In: Arroz: investigación e producción. Cali: CIAT, 1985. p. $387-399$

KRZYZANOWSKI, F. C.; FRANÇA-NETO, J. B.;

HENNING, A. A. Relato dos testes de vigor disponíveis para grandes culturas. Inf. ABRATES, v. 1, n. 2, p. 15-50, 1991.

LEITE, C. R. F.; ALMEIDA, J. C. V.; PRETE, C. E. C. Aspectos fisiológicos, bioquímicos e agronômicos dos herbicidas inibidores da ALS (AHAS). Londrina: 1998. $68 \mathrm{p}$.

MAGALHÃES Jr., A. M.; ANDRES, A.; AZAMBUJA, I. H. V. Evolução da produtividade do arroz irrigado no Rio Grande do Sul e meios para sua continuidade. In: AZAMBUjA, I. V. et al. (Eds.) Série culturas - Arroz. Porto Alegre: Comissão de Agricultura, Pecuária e Cooperativismo da Assembléia Legislativa do Estado do Rio Grande do Sul, 2002. p. 35-52.

MAGALHÃES Jr., A. M. et al. Aspectos genéticos, morfológicos e de desenvolvimento de plantas de arroz irrigado. In: GOMES, A. S.; MAGALHÃES JR., A. M. (Eds.). Arroz irrigado no Sul do Brasil. Brasília: Embrapa Informação Tecnológica, 2004. p. 143-235.

MATTOS, M. L. T. A cultura do arroz irrigado e o meio ambiente. In: GOMES, A.S.; MAGALHÃES JR., A. M. (Eds.). Arroz irrigado no Sul do Brasil. Brasília: Embrapa Informação Tecnológica, 2004. p. 861-899.

MENEZES, V. G.; RAMIREZ, H.; MARIOT, C. H. P. Seletividade de herbicidas em arroz irrigado. In: CONGRESSO BRASILEIRO DA CIÊNCIA DAS PLANTAS DANINHAS, 24., 2004, São Pedro. Anais... Londrina: SBCPD, 2004. CD-ROM.

NEWHOUSE, K.; WANG, T.; ANDERSON, P. Imidazolinone-tolerant crops. In: SHANER, D.L.; O'CONNOR, S.L. (Eds.). The imidazolinone herbicides. Boca Raton: CRC Press, 1991. p. 139-150.

PINTO, J. J. O. et al. Controle de capim-arroz com o herbicida penoxsulam aplicado em pós-emergência da cultura do arroz e das plantas daninhas. In: CONGRESSO BRASILEIRO DA CIÊNCIA DAS PLANTAS DANINHAS, 24., 2004, São Pedro. Anais... Londrina: SBCPD, 2004. CD-ROM.

SCHWEIZER, E. E.; LYBECKER, D. W.; WILES, L. J. Important biological information needed to bioeconomic weed management models. In: HATFIELD, J. L.; BUHLER, D. D.; STEWART, B. A. (Eds.). Integrated weed and soil management. Chelsea: Ann Arbor Press, 1998. p. 1-24. 
SHANER, D. Physiological effects of the imidazolinone herbicides. In: SHANER, D. L.; O'CONNOR, S. L. (Eds.). The imidazolinone herbicides. Boca Raton: CRC Press, 1991. p. 129-138.

SMITH Jr., R. J. Weed threshold in southern U.S. rice (Oryza sativa). Weed Technol., v. 2, p. 232-241, 1988.

SPRAGUE, C. L. et al. Palmer amaranth (Amaranthus palmeri) and common waterhemp (Amaranthus rudis) resistance to selected ALS-inhibiting herbicides. Weed Sci., v. 45 , p. 192-197, 1997.
VIDAL, R. A. Ação dos herbicidas. Porto Alegre: 2002. $89 \mathrm{p}$.

WALKER, A. et al. Herbicides in soil. In: ROBERTS, H. A. (Ed.). Weed control handbook: principles. Oxford: Blackwell Scientific Publications, 1982. p. $87-105$.

WORTHING, C. R.; RICHARDSON, W. G.; TAYLOR, W. A. Properties of herbicides. In: ROBERTS, H. A. (Ed.). Weed control handbook: principles. Oxford: Blackwell Scientific Publications, 1982. p. 106-157. 